Permanent link for this document : https://doi.org/10.33367/jiee.v1i1.671

Analisis Krtitis Konsep Kurikulum Pendidikan Islam Indonesia di Sekolah (SD, SMP, SMA, \& L SMK)

Oleh: Surhadi

\title{
ANALISIS KRITIS KONSEP KURIKULUM PENDIDIKAN ISLAM INDONESIA DI SEKOLAH (SD, SMP, SMA, SMK)
}

\author{
Nurhadi \\ Sekolah Tinggi Agama Islam (STAI) Al-Azhar Pekanbaru \\ alhadijurnal@gmail.com; alhadicentre@yahoo.co.id
}

\begin{abstract}
Basically every PAI curriculum development requires a clear and solid foundation, so that it is not easily swayed by the flow of transformation and innovation in education and learning that is so powerful as it has been lately. If the innovation in general tends to be top-down innovation through the power coercion strategy or coercion from the superiors in power. The change in curriculum from the KBK to KTSP is expected to be able to make Islamic religious education more able to make the quality of religious education more able to make changes in Indonesia. In addition to changing the morals of better students, it is hoped that it can also increase knowledge. In accordance with the objectives of the curriculum changes themselves who want to improve the quality of students, both intellectual, emotional and spiritual quality.
\end{abstract}

\begin{abstract}
Abstrak
Pada dasarnya setiap pengembangan kurikulum PAI memerlukan landasan yang jelas dan kokoh, sehingga tidak mudah terombang-ambing oleh arus transformasi dan inovasi pendidikan dan pembelajaran yang begitu dahsyat sebagaimana yang terjdai akhir-akhir ini. Apabila inovasi itu pada umumnya cenderung bersifat top-down innovation melalui stratergi power coersie atau pemaksaan dari atasan yang berkuasa. Perubahan kurikulum dari KBK ke KTSP diharapkan bisa membuat pendidikan agama Islam lebih bisa membuat kualitas pendidikan agama menjadi lebih bisa membuat perubahan di Indonesia. Selain mengubah akhlak peserta didik lebih baik diharapkan juga bisa membuat knowledge semakin meningkat. Sesuai dengan tujuan dari perubahan kurikulum itu sendiri yang menginginkan peningkatan mutu peserta didik, baik mutu intelektual, emosional maupun spritual.
\end{abstract}

Kata Kunci: Analisis, Kritis, Konsep, Kurikulum, Pendidikan Islam.

\section{Pendahuluan}

Pendididikan Islam adalah pendidi-kan yang sengaja didirikan dan diseleng-garakan dengan hasrat dan niat (rencana yang sungguhsungguh) untuk mengejawan-tahkan 
ajaran dan nilai-nilai Islam, sebagaimana tertuang atau terkandung dalam visi, misi, tujuan, program kegiatan maupun pada praktik pelaksanaan kependidikannya. Pengembangan kurikulum pendidikan agama Islam (PAI) merupakan salah satu perwujudan dari pengembangan sistem pendidikan Islam.

Di tengah-tengah pesatnya inovasi pendidikan, terutama dalam konteks pengembangan kurikulum, sering kali para guru PAI merasa kebingungan dalam menghadapinya. Apalagi inovasi pendidikan tersebut cenderung bversifat top-down innovation dengan stratergi power coersive atau stratergi pemaksaan dari atasan (pusat) yang berkuasa. Inovasi ini sengaja diciptakan oleh atasan sebagai usaha untuk meningkatkan mutu pendidikan agama Islam ataupun untuk meningkatkan efesiensi serta efektivitas pelaksanaan PAI dan sebagainya. Inovasi seperti ini dilakukan dan diterapkan kepada bawahan dengan cara mengajak, menganjurkan dan bahkan memaksakan apa yang menurut pencipta itu baik untuk kepentingan bawahannya. Dan bawahan tidak mempunyai otoritas untuk menolak pelaksanaanya.
Karena itu, ada kesan yang cukup memprihatinkan dari masyarakat bahwa seolah-olah setiap ganti menteri akan diikuti dengan perubahan kebijakan. Untuk mengantisipasi masalah tersebut, agaknya para guru PAI perlu memahami dan memiliki landasa pijak yang jelas dan kokoh, sehingga tidak mudah terombang-ambing oleh arus transformasi dan inovasi tersbut ternyata bukan dibangun dari eksperimen pendidikan agama, tetapi dari bidang lain yang memiliki karateristik yang berbeda pula, sedangkan pendidikan agama hanya bersifat latah. Sebagaiman tertuang dalam UU Nomor 20/2003 tentang sistem Pendidikan Nasional, terutama pada penjelasan Pasal 37 ayat (1) bahwa pendidikan agama dimaksudkan untuk membentuk peserta didik menjadi manusia yang beriman dan bertakwa kepada Tuhan Yang Maha Esa serta berakhlak mulia.

\section{Pembahasan}

\section{Pengertian Telaah Kurikulum PAI}

Telaah adalah penyelidikan; kajian; pemeriksaan; penelitian. ${ }^{1}$ Kurikulum adalah rencana tertulis tentang kemampuan yang harus dimiliki berdasarkan standar nasional, materi yang perlu dipelajari

\footnotetext{
${ }^{1}$ Departemen Pendidikan Nasional, Kamus Besar Bahasa Indonesia (Jakarta: Balai Pustaka, 2015), hlm. 160. 


\section{Oleh: Nurhadi}

dan pengalaman belajar yang harus dijalani untuk mencapai kemampuan tersebut dan evaluasi yang perlu pencapaian kemampuan peserta didik, serta seperangkat peraturan yang berkenaan dengan pengalaman belajar peserta didik dalam mengambangkan potensi dirinya pada satuan. $^{2}$

Pendidikan berusaha mengembangkan potensi individu agar mampu berdiri sendiri. Untuk itu individu perlu diberi berbagai kemampuan dalam pengembangan berbagai hal seperti: konsep, prinsip kreativitas, tanggung jawab, dan keterampilan. Dengan kata lain perlu mengalami perkembangan dalam aspek kognitif, afektif, dan psikomotor. Demikian pula individu jangan makhluk sosial yang selalu berinteraksi dengan lingkungan sesamanya. ${ }^{3}$

Kurikulum adalah rencana tertulis tentang kemampuan yang harus dimilki berdasarkan standar nasional, materi yang perlu dipelajari dan pengalaman belajar yang harus dijalani untuk mencapai kemampuan tersebut, dan evaluasi yang perlu dilakukan untuuk menentukan tingkat pencapaian kemampuan

\footnotetext{
20emar Hamalik, Manajemen pengembangan Kurikulum, (Bandung: PT Remaja Rosdakarya, 2016), hlm. 91.

${ }^{3}$ Nanang Fatah, Landasan pengembangan Pendidikan, (Bandung: PT Remaja Rosdakarya, 2016), hlm. 5.

peserta didik, serta seperangkat peratuaran yang berkenaan dengan pengalaman belajar peserta didik dalam mengembagkan potensi dirinya pada satuan pendidikan tertentu. ${ }^{4}$

Pendidikan berusaha mengembangkan potensi individu agar mampu berdiri sendiri. Untuk itu individu perlu diberi berbagai kemampuan dalam pengembangan berbagai hal, seperti: konsep, prinsip, kreativitas, tanggung jawab, dan keterampilan. Dengan kata lain perlu mengalami perkembangan dalam aspek kognitif, afektif dan psikomotor. Demikian opula individu juga makhluk sosial yang selalu berinteraksi dengan lingkungan sesamanya.

\section{Berbagai Kritik Terhadap PAI}

Selama ini pelaksanaan pendidikan agama yang berlangsung di sekolah masih mengalami banyak kelemahan. Mochtar Bucjari menilai pendidikan agama masih gagal. ${ }^{5}$ Kegagalan ini disebabkan karena praktik pendidikannya hanya memperhatikan aspek kognitif semata dari pertumbuhan semata dari pertumbuhan kesadaran nilai${ }^{4}$ Oemar $\quad$ Hamalik,
pengembangan Kurikulum, hlm. 91.
5Mochtar Bukhori, Spektrum Problematika
Pendidikan di Indonesia. (Jakarta: Tirta Wacana
Yogya. 2016), hlm. 23 
nilai (agama), dan mengabaikan pembinaan aspek afektif dan konatifvolitif, yakni kemauan dan tekad untuk mengamlkan nilai-nilai ajaran aama. Akibatnya terjadi kesenjangan antara pengetahuan dan pengamalan, antara gnosis dan praxis dalam kehidupan nilai agama. Atau dalam praktik pendidikan agama berubah menjadi pengajaran agama, sehingga tidak mampu membentuk pribadi-pribadi bermoral, padahal intisari dari pendidikan agama adalah pendidikan moral. ${ }^{6}$

\section{Pengembangan Kurikulum PAI}

Indonesia terdiri lebih dari 3500 buah pulau yang dihuni berbagai suku bangsa yang mempunyai berbagai macam adatistiadat, bahasa, kebudayaan, agama, kepercayaan dan sebagainya. Berbagai kekayaan alam baik yang terdapat di darat, laut, flora, fauna, dan berbagai hasil tambang yang kesemuanya merupakan sumber daya alam. Kebudayaan nasional yang didukung oleh berbagai nilai kebudayaan daerah yang luhur beradab yang merupakan nilai jati diri yang menjiwai perilaku manusia dan masyarakat dalam segenap aspek kehidupan, baik dalam lapangan industri, kerajinan, industri rumah tangga, jasa pertanian (agro

\footnotetext{
${ }^{6}$ Nasution, Harun, Islam ditinjau dari berbagai Aspeknya, (Jakarta: UI Press, 2015), hlm. 17
}

industri dan agro bisnis) perkebunan perikanan, peternakan, pertanian hortikultura (sayur-sayuran, buahbuahan, tanaman hias, dan tanaman obat-obatan), kepariwisataan, pemeliharaan lingkungan hidup sehingga terjadi kesesuaian, keselarasan, dan keseimbangan yang dinamis. Kurikulum selain mengacu pada karakteristik peserta didik, perkembangan ilmu dan teknologi pada zamannya juga mengacu kepada kebutuhan-kebutuhan masyarakat. ${ }^{7}$

Dari beberapa definisi tentang kurikulum tersebut, maka dapat dipahami bahwa pengembangan kurikulum Pendidikan Agama Islam (PAI) dapat diartikan sebagai: (1) kegiatan menghasilkan kurikulum PAI; atau (2) peroses yang mengaitkan suatu komponen dengan yang lainnya untuk menghasilkan kurikulum PAI yang lebih baik; dan/atau (3) kegiatan penyusunan (desain), pelaksanaan, penilaian dan penyempurnaan kurikulum PAI.

Dalam realitas sejarahnya, pengembangan kurikulum PAI tersebut ternyata mengalami perubahan-perubahan paradigma, walaupun dalam beberapa hal tertentu paradigma sebelumnya masih tetap dipertahankan hingga sekarang. Hal ini dpat dicermati dari

${ }^{7}$ Dakir, Perencanaan dan Pengembangan Kurikulum, (Jakarta: Rineka Cipta, 2014), hlm. 100.

el Bidayah: Journal of Islamic Elementary Education Volume 1, Nomor 1, Maret 2019 


\section{Oleh: Nurhadi}

fenomena berikut: (1) perubahan dari tekanan pada hapalan dan daya ingat tentang teks-teks dari ajaranajaran Agama Islam, serta disiplin mental spritual sebagaimana pengaruh dari Timur Tengah, kepada pemahaman tujuan, makna dan motivasi beragama Islam untuk mencapai tujuan pembelajaran PAI; (2) perubahan dari cara berpikir tekstual, normatif, dan absolutis kepada cara berpikir historis, empiris, dan kontekstual dalam memahami dan menjelaskan ajaranajaran dan nilai-nilai agama Islam; (3) perubahan dari tekanan pada produk atau hasil pemikiran keagamaan Islam dari para pendahulunya kepada proses atau metodologinga sehingga menghasilkan produk tersebut; dan (4) perubahan pada pola pengembangan kurikulum PAI yang hanya mengandalkan pada para pakar dalam memilih dan menyusun isis kurikulum PAI kearah keterlibatan yang luas dari para pakar, guru, peserta didik, masyarakat untuk mengidensifikasi tujuan PAI dan cara-cara mencapainya. ${ }^{8}$

Banyak kalangan, termasuk aparat Depdiknas dan Dinas Pendidikan Kabupaten/Kota membuat statement bahwa Kurikulum 2004 (atau KBK) tidak terlalu jauh berbeda dengan Kurikulum 2006 yang disusun oleh Badan Standar Nasional Pendidikan (BSNP) dan baru ditetapkan pemberlakuannya oleh Mendiknas melalui Peraturan Mendiknas No. 24 Tahun 2006 tanggal 2 Juni 2006. Saya tidak tahu, apakah penyataan mereka itu dimaksudkan untuk "menghibur guru" agar tidak resah menghadapi perubahan kurikulum ini. Mengingat Kurikulum 2004 ini masih dalam taraf ujicoba yang lebih luas sejak tahun pembelajaran 2004/2005 dan belum semua sekolah sudah menerapkan secara utuh Kurikulum 2004. Namun apa daya, kini sudah dimunculkan kurikulum baru, Kurikulum 2006. Sehingga muncullah statement yang "menghibur" tersebut.

Hal ini adalah ironis, karena menunjukkan pemahaman yang sangat dangkal mereka terhadap Kurikulum 2006 tersebut. Saya menduga mereka hanya "mengulangulang" pernyataan dari BSNP, aparat Pusat Kurikulum, Pejabat Depdiknas yang bermaksud meredam agar Kurikulum 2006 tidak mendapat tentangan dari ujung tombak pendidikan : guru dan sekolah, atau gejolak yang meresahkan masyarakat dan dunia pendidikan. Jika saja mereka sudah melakukan

\footnotetext{
8Muhaimin, Pengembangan Kurikulum Pendidikan Agama Islam, (Jakarta: PT Raja Grafido Persada, 2017), hlm. 10-11. 
pembandingan secara mendalam kedua kurikulum tersebut, niscaya mereka akan mengatakan bahwa Kurikulum 2004 dengan Kurikulum 2006 berbeda secara nyata, secara signifikan. Memang harus diakui dalam beberapa hal ada kesamaan atau kemiripan antara keduanya. Berikut ini saya rangkum perbedaan dan persamaan antara Kurikulum 2004 dan Kurikulum 2006 (periksa tabel): ${ }^{9}$

\section{Perbandingan Kurikulum 2004 dan 2006}

\begin{tabular}{|c|c|c|}
\hline Aspek & Kurikulum 2004 & Kurikulum 2006 \\
\hline 1. Landasan Hukum & $\begin{array}{l}\text { - Tap MPR/GBHN Tahun 1999-2004 } \\
\text { - UU No. 20/1999 - Pemerintah-an } \\
\text { Daerah } \\
\text { - UU Sisdiknas No 2/1989 kemudian } \\
\text { diganti dengan UU No. 20/2003 } \\
\text { - PP No. } 25 \text { Tahun } 2000 \text { tentang } \\
\text { pembagian kewenangan }\end{array}$ & $\begin{array}{l}\text { - UU No. 20/2003 - Sisdiknas } \\
\text { PP No. 19/2005 - SPN } \\
\text { - Permendiknas No. 22/2006 - } \\
\text { Standar Isi } \\
\text { - Permendiknas No. 23/2006 - } \\
\text { Standar Kompetensi Lulusan }\end{array}$ \\
\hline $\begin{array}{l}\text { 2. Implementasi/ } \\
\text { Pelaksanaan } \\
\text { Kurikulum }\end{array}$ & $\begin{array}{l}\text { - Bukan dengan Keputusan/ Peraturan } \\
\text { Mendiknas RI } \\
\text { - Keputusan Dirjen Dikdasmen } \\
\text { No.399a/C.C2/Kep/DS/2004 Tahun } \\
\text { 2004. } \\
\text { - Keputusan Direktur Dikme-num No. } \\
\text { 766a/C4/MN/2003 Tahun 2003, dan } \\
\text { No. 1247a/C4/MN/2003 Tahun 2003. }\end{array}$ & $\begin{array}{l}\text { Peraturan Mendiknas RI No. 24/2006 } \\
\text { tentang Pelaksanaan Peraturan } \\
\text { Menteri No. } 22 \text { tentang SI dan No. } 23 \\
\text { tentang SKL }\end{array}$ \\
\hline $\begin{array}{l}\text { 3. Ideologi } \\
\text { Pendidikan yang } \\
\text { dianut }\end{array}$ & $\begin{array}{l}\text { Liberalisme Pendidikan : terciptanya } \\
\text { SDM yang cerdas, kompeten, profesional } \\
\text { dan kompetitif }\end{array}$ & $\begin{array}{l}\text { Liberalisme Pendidikan : terciptanya } \\
\text { SDM yang cerdas, kompeten, } \\
\text { profesional dan kompetitif }\end{array}$ \\
\hline 4. Sifat (1) & $\begin{array}{l}\text { Cenderung Sentralisme Pendidikan : } \\
\text { Kurikulum disusun oleh Tim Pusat } \\
\text { secara rinci; Daerah/Sekolah hanya } \\
\text { melaksanakan }\end{array}$ & $\begin{array}{l}\text { Cenderung Desentralisme Pendidikan } \\
\text { : Kerangka Dasar Kurikulum disusun } \\
\text { oleh Tim Pusat; Daerah dan Sekolah } \\
\text { dapat mengembangkan lebih lanjut. }\end{array}$ \\
\hline 5. Sifat (2) & $\begin{array}{l}\text { Kurikulum disusun rinci oleh Tim Pusat } \\
\text { (Ditjen Dikmenum/ Dikmenjur dan } \\
\text { Puskur) }\end{array}$ & $\begin{array}{l}\text { Kurikulum merupakan kerangka } \\
\text { dasar oleh Tim BSNP }\end{array}$ \\
\hline 6. Pendekatan & $\begin{array}{l}\text { - } \text { Berbasis Kompetensi } \\
\text { - Terdiri atas : SK, KD, MP dan } \\
\text { Indikator Pencapaian }\end{array}$ & $\begin{array}{l}\text { Berbasis Kompetensi } \\
\text { Hanya terdiri atas : SK dan KD. } \\
\text { Komponen lain dikembangkan oleh } \\
\text { guru }\end{array}$ \\
\hline 7. Struktur & $\begin{array}{l}\text { - } \text { Berubahan relatif banyak } \\
\text { dibandingkan kurikulum sebelumnya } \\
\text { (1994 suplemen 1999) } \\
\text { - Ada perubahan nama mata pelajaran } \\
\text { - Ada penambahan mata pelajaran } \\
\text { (TIK) atau penggabungan mata } \\
\text { pelajaran (KN dan PS di SD) }\end{array}$ & $\begin{array}{l}\text { - Penambahan mata pelajaran } \\
\text { untuk Mulok dan Pengem-bangan } \\
\text { diri untuk semua jenjang sekolah } \\
\text { - Ada pengurangan mata pelajaran } \\
\text { (Misal TIK di SD) } \\
\text { - Ada perubahan nama mata } \\
\text { pelajaran } \\
\text { - KN dan IPS di SD dipisah lagi }\end{array}$ \\
\hline
\end{tabular}

${ }^{9}$ Nanang Rijono, "Kontribusi Kecil untuk Dunia Pendidikan Indonesia", (online) available: http://rijono.wordpress.com/2008/02/28/kur 6 ikulum-2004-kbk-kurikulum-2006-ktspmemang-berbeda-secara-signifikan/, diakses pada tanggal 27 Oktober 2017.

el Bidayah: Journal of Islamic Elementary Education Volume 1, Nomor 1, Maret 2019 
Permanent link for this document : https://doi.org/10.33367/jiee.v1i1.671

Analisis Krtitis Konsep Kurikulum Pendidikan Islam Indonesia di Sekolah (SD, SMP, SMA, \&Z SMK)

Oleh: Nurhadi

\begin{tabular}{|c|c|c|}
\hline & & $\begin{array}{l}\text { - Ada perubahan jumlah jam } \\
\text { pelajaran setiap mata pelajaran }\end{array}$ \\
\hline 8. Beban Belajar & \begin{tabular}{|ll} 
Jumlah Jam/minggu : \\
- & SD $/ \mathrm{MI}=26-32 / \mathrm{minggu}$ \\
- & $\mathrm{SMP} / \mathrm{MTs}=32 / \mathrm{minggu}$ \\
- & $\mathrm{SMA} / \mathrm{SMK}=38-39 / \mathrm{minggu}$ \\
- & Lama belajar per $1 \mathrm{JP}:$ \\
- & $\mathrm{SD}=35$ menit \\
- & $\mathrm{SMP}=40$ menit \\
- & $\mathrm{SMA} / \mathrm{MA}=45$ menit
\end{tabular} & 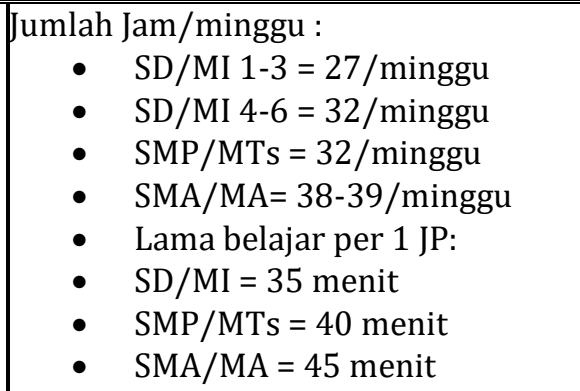 \\
\hline $\begin{array}{l}\text { 9. Pengembangan } \\
\text { Kurikulum lebih } \\
\text { lanjut }\end{array}$ & $\begin{array}{l}\text { - Hanya sekolah yang mampu dan } \\
\text { memenuhi syarat dapat } \\
\text { mengembangkan KTSP. } \\
\text { - Guru membuat silabus atas dasar } \\
\text { Kurikulum Nasional dan RP/Skenario } \\
\text { Pembelajaran }\end{array}$ & $\begin{array}{l}\text { - Semua sekolah /satuan pendidikan } \\
\text { wajib membuat KTSP. } \\
\text { - Silabus merupakan bagian tidak } \\
\text { terpisahkan dari KTSP } \\
\text { - Guru harus membuat Rencana } \\
\text { Pelaksanaan Pembelajaran (RPP) }\end{array}$ \\
\hline $\begin{array}{l}\text { 10. Prinsip } \\
\text { Pengembangan } \\
\text { Kurikulum }\end{array}$ & 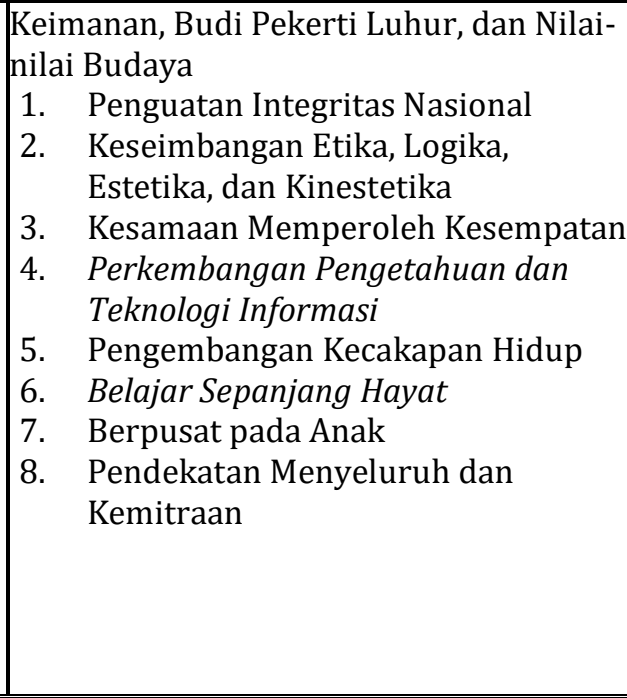 & $\begin{array}{l}\text { Berpusat pada potensi, } \\
\text { perkembangan, kebutuhan, dan } \\
\text { kepentingan peserta didik dan } \\
\text { lingkungannya } \\
\text { 1. Beragam dan terpadu } \\
\text { 2. Tanggap terhadap } \\
\text { perkembangan ilmu } \\
\text { pengetahuan, teknologi, dan } \\
\text { seni } \\
\text { 3. Relevan dengan kebutuhan } \\
\text { kehidupan } \\
\text { 4. Menyeluruh dan berkesinam- } \\
\text { bungan } \\
\text { 5. Belajar sepanjang hayat } \\
\text { 6. Seimbang antara kepentingan } \\
\text { nasional dan kepentingan } \\
\text { daerah }\end{array}$ \\
\hline $\begin{array}{l}\text { 11. Prinsip } \\
\text { Pelaksanaan } \\
\text { Kurikulum }\end{array}$ & $\begin{array}{l}\text { 1. Tidak terdapat prinsip pelaksanaan } \\
\text { kurikulum }\end{array}$ & \begin{tabular}{|l} 
1. Didasarkan pada potensi, \\
perkembangan dan kondisi \\
peserta didik untuk menguasai \\
kompetensi yang berguna bagi \\
dirinya. \\
2. Menegakkan lima pilar belajar: \\
- $\quad$ Belajar untuk beriman dan \\
bertakwa kepada Tuhan YME, \\
- Belajar untuk memahami dan \\
menghayati, \\
- Belajar untuk mampu \\
melaksanakan dan berbuat \\
secara efektif, \\
Belajar untuk hidup bersama \\
dan berguna bagi orang lain,
\end{tabular} \\
\hline
\end{tabular}




\begin{tabular}{|c|c|c|}
\hline & & 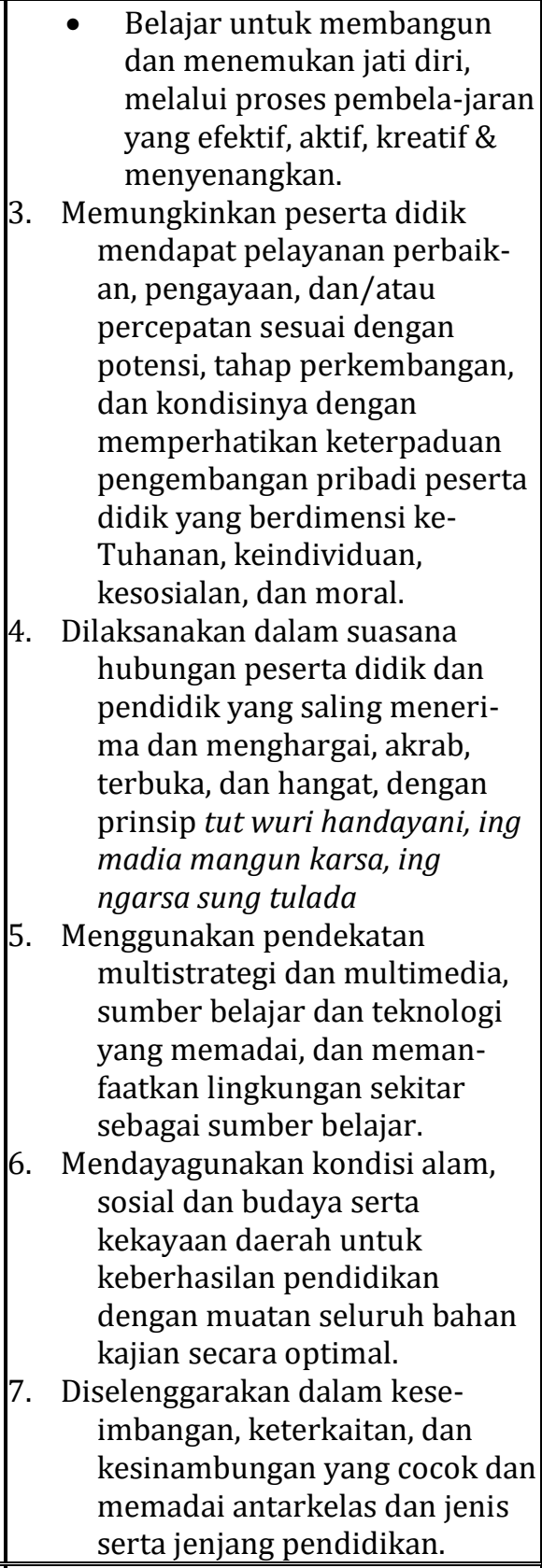 \\
\hline $\begin{array}{l}\text { 12. Pedoman } \\
\text { Pelaksanaan } \\
\text { Kurikulum }\end{array}$ & $\begin{array}{ll}\text { 1. } & \text { Bahasa Pengantar } \\
\text { 2. } & \text { Intrakurikuler } \\
\text { 3. } & \text { Ekstrakurikuler } \\
\text { 4. } & \text { Remedial, pengayaan, akselerasi } \\
\text { 5. } & \text { Bimbingan \& Konseling } \\
\text { 6. } & \text { Nilai-nilai Pancasila } \\
\text { 7. } & \text { Budi Pekerti } \\
\text { 8. } & \text { Tenaga Kependidikan } \\
\text { 9. } & \text { Sumber dan Sarana Belajar } \\
\text { 10. } & \text { Tahap Pelaksanaan } \\
\text { 11. } & \text { Pengembangan Silabus } \\
\text { 12. } & \text { Pengelolaan Kurikulum } \\
\end{array}$ & $\begin{array}{l}\text { 1. Tidak terdapat pedoman } \\
\text { pelaksanaan kurikulum seperti pada } \\
\text { Kurikulum 2004. }\end{array}$ \\
\hline
\end{tabular}


Tidak terdapat pedoman pelaksanaan kurikulum seperti pada Kurikulum 2004. Untuk sementara baru 12 aspek yang saya temukan, dimana hanya 2 (dua) hal saja yang sama, yakni landasan ideologis dan pendekatan yang digunakan. Sementara 10 aspek lainnya berbeda sangat nyata, meskipun ada kemiripan pada butir-butir tertentu.

\section{Perbedaan Esensi SK Dan KD}

Hal yang sering dikatakan oleh pejabat Depdiknas dan Dinas Pendidikan, bahwa Kurikulum 2004 dan 2006 adalah pada aspek Standar Kompetensi dan Kompetensi Dasarnya. Dalam Kurikulum SD/MI 2004 hanya terdapat satu SK masingmasing jenjang kelas untuk hampir semua mata pelajaran. Namun dalam Kurikulum 2006 terdapat dua SK untuk setiap jenjang kelas untuk seluruh mata pelajaran plus rinciannya pada kelas dan pelajaran tertentu. Masing-masing SK sudah diplot mana yang untuk semester 1 dan 2. Sementara itu, batasan semacam ini tidak ada pada Kurikulum 2004.

KD-KD yang ada dalam Kurikulum 2004 ada yang masih digunakan dengan rumusan yang sama atau mirip dengan rumusan KD dalam Kurikulum 2006. Ada beberapa KD Kurikulum 2004 yang dibuang. Ada beberapa KD yang baru dalam Kurikulum 2006. Sehingga kalau ruang lingkup materi (scope) ini dijadikan ukuran, maka memang tidak terlalu banyak perbedaan Kurikulum 2004 dengan Kurikulum 2006. Namun KD-KD yang ada dalam Kurikulum 2004 tersebut direkonstruksikan kembali, ditata kembali sedemikian rupa sehingga menjadi sangat berbeda dalam urutannya (sequence).

\section{Pendekatan-pendekatan dalam Pengem-bangan Kurikulum PAI}

Di dalam teori kurikulum setidak-tidaknya terdapat empat pendekatan yang dapat digunakan dalam pengembangan kurikulum, yaitu: pendekatan subjek akademis; pen-dekatan humanistis; pendekatan teknologis; dan pendekatan karakteristik PAI sebagaimana uraian pada bab terdahulu, maka pengembangan kurikulum pendidikan agama Islam (PAI) dapat menggunakan pendekatan eklektrik, yakni dapat memilih yang terbaik dari keempat pendekatan tersebut sesuai dengan karak-teristiknya.

\section{Pendekatan Subjek Akademis}

Pendekatan subjek akademis dalam menyusun kurikulum atau program pendidikan didasarkan pada sistematisasi disiplin ilmu masing-masing. Setiap ilmu pengetahuan memiliki sistenmatisasi 
tertentu yang berbeda dengan sistematisasi ilmu lainnya. Pengembangan kurikulum subjek akademis dilakukan dengan cara menetapkan lebih dahulu mata pelajaran/mta kuliah apa yang harus dipelajari peserta didik, yang diperlukan untuk (persiapan) pengem-bangan disiplin ilmu.

Pendidikan agama Islam di sekolah meliputi aspek AL-Quran/ Hadis, keimanan, akhlak, ibadah/ muamalah, dan tarikh/sejarah umat Islam. Di madrasah, aspek-aspek tersebut dijadikan sebagai sub-sub mata pelajaran PAI yang meliputi: mata pelajaran Alquran-Hadis, Fiqih, Akidah-Akhlak, dan Sejarah (kebudayaan) Islam.

\section{Pendektan Humanistis}

Pendekatan humanists dalam pengembangan kurikulum bertolak dari ide "memanusiakan manusia". Penciptaan konteks yang akan memberi peluang manusia untuk menjadi lebih huma, untuk memperinggi harkat manusia merupakan dasar filosofi, dasar teori, dasar evaluasi dan dasar pengembaangan program pendidikan.]

Dalam kegiatan pembelajaran guru perlu memposisikan guru sebagai fasilitator yang membimbing dan mengarahkan jalannya pembelajaran; atau memposisikan peserta didik sebagai orang yang sedang belajar, mengaktualisaskan dan mengem-bangkan potensipotensinya. Adapun menjadikan peserta didik sebagai pendengar melalui metode ceramah dilakukan pada tahap berikutnya, yang berfungsi sebagi konfirmasi atau memperkuat apa yang dipelajari peserta didik, atau mediator bila terdapat pendangan-pandangan yang kontroversial, atau mungkin peserta didik sudah sangat memerlukan bantuan penjelasan guru, demikian seterusnya.

\section{Pendekatan teknologis}

Pendekatan teknologis dalam menyusun kurikulum atau program pendidikan pendidikan bertolak dari analisis kompetensi yang dibutuhkan ntuk melaksanakan tugas-tugas tertentu. Materi yang diajarkan, kriteria evaluasi sukses, dan stratergi belajarnya ditetapkan sesuai analisis tuas (job analysis) tersebut. Kurikulum berbasis kompetensi yang saat ini sedang digalakkan di sekolah/ nmadrasah termasuk dalam kategori pendekatan teknologis.

\section{Pendekatan \\ Rekonstruksi Sosial \\ Pendekatan rekonstruksi sosial dalam menyusun kurikulum atau program pendidikan keahlian bertolak dari problem yang dihadapi}


Oleh: SNurhadi

masyarakat, untuk selanjutnya denga memerankan ilmu-ilmu dan teknologi, serta bekerja secara kooperatif dan kolaboratif, akan dicarikan upaya pemecahannya menuju pembentukan masyarakat yang lebih baik.

\section{Fungsi Kurikulum PAI}

1) Bagi Sekolah/Madrasah yang Bersang-kutan: Sebagai alat untuk mencapai tujuan pedidikan agama Islam yang diinginkan. Pedoman untuk mengatur kegiatan-kegiatan pendidikan agama Islam di sekolah/madrasah.

2) Bagi Sekolah/Madrasah di Atasnya: a). Melakukan penyesusaian; b). Menghindari keteulangan sehingga boros waktu; c). Menjaga kesenimbungan; d). Bagi masyarakat: masyarakat sebagai pengguna lulusan (user), sehingga sekolah/madrasah harus mengetahui hal-hal yang menjadi kebutuhan masyarakat dalam konteks pengembangan PAI. Adanya kerja sama yang harmonis dalam hal pembenahan dan pengembangan kurikulum PAI. ${ }^{10}$

\section{Mencermati Pengembangan PAI di Sekolah/Perguruan Tinggi}

Pemahaman tenang pendidikan agama Islam (PAI) di sekolah/perguruan tinggi dari dua sudut pandangan, yaitu PAI sebagai aktivitas dan PAI sebagai fenomena. PAI sebagai aktivitas,berarti upaya yang secara sadar dirancang untuk membantu seseorang atau sekelompok orang dalam mengembangkan pandangan hidup (bagaimana orang akan menjalani dan memanfaatkan hidup dan kehidupannya), sikap hidup, dan keterampilan hidup, baik yang bersifat manual(petunjuk praktis) maupun mental dan sosial yang bernapaskan atau dijiwai oleh ajaran dan nilai-nilai Islam. Sedangkan PAI sebagai fenomena adalah peristiwa perjumpaan antara dua orang atau lebih dan/atau penciptaan suasana yang dampaknya ialah berkembangnya suatu pandanga hidup yang bernapaskan atau dijiwai oleh ajaran dan nilai-nilai Islam, yang diwujudkan dalam sikap hidup keterampilan hidup pada salah satu atau beberapa pihak. ${ }^{11}$

Persoalan

manajemen kurikulum dan pembelajaran yang sangat berbeda antara Kurikulum 2004 dengan Kurikulum 2006. Kedua persoalan ini akan sangat dirasakan

${ }^{11}$ Muhaimin, Pengembangan Kurikulum Pendidikan Agama Islam, (Jakarta: PT Raja Grafido Persada, 2017), hlm. 21 
oleh para guru pengajarnya karena mereka adalah perencana, pelaksana dan penilai pembelajaran. Merekalah yang akan dibingungkan setiap hari dalam melak-sanakan tugasnya. Jadi, sekali lagi, jika perbedaan antara kedua kurikulum tersebut sangat sugnifikan. Dan para guru adalah "korban" pertama dari perubahan kurikulum

ini.

Disukrus tentang pengembangan pendidikan agama Islam di Indonesia yang di-presentasikan oleh para ahli dan pemerhati pendidikan Islam, baik melalui tulisan-tulisan mereka di berbagai buku, majalah, jurnal, dan sebagainyamaupun melalui kegiatan seminar, penataran dan lokakarya, serta kegiatan lainnya, telah memperkaya wawasan dan visi kita dalam pendidikan agama Islam di Indonesia. Berbagai pemikiran dan pengalaman mereka perlu dipotret, ditata, dan didudukkan dalam suatu paradigma, sehingga model-model, orientasi dan langkah-langkah yang hendak dituju menjadi semakin jelas. Lagipula kalau sesorang hendak melakukan pengembanga dan penyempurnaan, maka kata kuncinya sudahdapat dipegang, sehingga tidak akan terjadinya salah letak, arah dan langkah, yang pada girilannya dapat menimbulkan sikap overacting dalam menyingkapi paradigma tertentu.

\section{Pendidikan Agama Islam dalam Sorotan}

Undang-undang nomor 14 tahun 2005 merupakan jaminan untuk meningkatkan output mutu pendidikan. Memang substansi UU tersebut secara langsung menyangkut jaminan karier dan jaminan perbaikan nasib para guru dan dosen, tetapi sebenarnya misalnya jauh lebih besar pada peningkatan kualitas sumber daya manusia tunas-tunas muda bangsa. ${ }^{12}$ Bangsa Indonesia masih sedang mengalami suasan keprihatinana yang bertubi-tubi. Hasil survei menunjukkan bahwa negeri kita masih bertengger dalam jajaran negara yang paling korup di dunia, KKN melanda di berbagai intuisi, disiplin makin longgarsemakin meningkatnya tindak kriminal, tindak kekerasan, aarchisme, premanisme, konsumsi minuman keras dan narkoba sudah melanda di kalangan pelajar dan mahasiswa. Masyarakat kita juga cenderung mengarah pada masyarakat paguyuban (gemeinschaft) sudah diting-galkan, yang tampak di permukaan adalah timbulnya konflik kepentingan-

\footnotetext{
12Dodi Nandika, Pendidikan di Tengah Gelombang Perubahan, (Jakarta: Pustaka LP3ES, 2017), hlm. 7 
kepentingan, baik kepentingan individu, kelompok, agama, etnis, politik maupun kepentingan lainnya.

Hasil survey dari Internasional Country Risk Guide Index (ICRGI), sejak tahun 1992 hingga 2000. negara-negara yang matoritas penduduknya beragama Islam, Kristen, Hindu/Budha atau lainnya banyak yang indeks korupsinya tinggi (di atas 7), seperti Indonesia (sekarang 9,25), Pakistan, Banglades, Nigeria, Rusia, Argentina, Meksiko, Filipina, Kolombia, dan Thailand. Sebaliknya, ada pula negara-negara yang mayoritas penduduknya beragama Islam, Kristen, atau lainnya, seperti Iran, Arab Saudi< Syiria, AS, Kanada, Inggris, dan lainlain, indeks korupsinya rendah.

Timbulnya krisis akhlak atau moral bukan hanya disebabkan karena kegagalan pendidikan agama. Dengan bertolak dari suatu pandangan bahwa kegiatan pendidikan merupakan suatu proses penanaman dan pengembangan seperangkat nilai dan norma yang implisit dalam setiap bidan studi sekaligus gurunya, maka tugas mendidik akhlak yang mulia sebenarnya bukan hanya menjadi tanggung jawab guru PAI an sich. Apalagi iman dan takwa terhadap Tuhan Yang Maha Esa merupakan persyaratan utama bagi setiap guru/dosen, yang secara praktis akan berimplikasi pada keharusan setia guru/dosen untuk mengimplisitkan nilai-nilai akhlak yang mulia dalam setiap bidang studi yang dipelajari oleh dan diajarkan kepada peserta didik. Pandangan semacam ini juga dikemukakan oleh Ibnu Maskawaih (330 H/940 M - 421 $\mathrm{H} / 1030 \mathrm{M}$ ), bahwa setiap ilmu atau mata pelajaran yang diajarakan oleh guru/pendidik harus memperjuangkan terciptanya akhlak yang mulia.

Jika krisis akhlak atau moral merupakan pangkal dari krisis multidimensional, sedangkan pendidikan agama Islam banyak menggarap masalah akhlak, maka perlu ditelaah apa yang menjadi penyebab titik lemah dari pendidikan agama tersebut. Melalui kajian tersebut diharapkan dapat dijadikan pegangan bagi para pelaksana pendidikan agama Islam, dan bahan pertimbangan bagi para pengambil kebijakan, sekaligus sebagai wacana pengembangan pendidikan agama Islam yang perlu diteliti lebih lanjut oleh para ilmuan dan pemerhati pendidikan agama Islam.

\section{Pengembangan Kurikulum PAI Menatap Inovasi Pendidikan}

Indonesia terdiri lebih dari 35.3500 buah pulau yang dihuni oleh berbagai bangsa yang mempunyai berbagai macam adat-istiadat, 
Oleh: SNurhadi

bahasa, kebudayaan, agama, down innovation melalui stratergi kepecayaan, dan sebagaunya. Berbagai kekayaan alam baik yang terdapat di darat, laut, flora, fauna, dan berbagai hasil tambang yang kesemuanya merupakan SDA. Kebudayaan nasional yag didukung oleh berbagai nilai kebudayaan daerah yang luhur beradab yang merupakan nilai jati diri yang menjiwai perilaku manusia dan masyarakat dalam segenap aspek kehidupan, baik dalam lapangan industri dan agrobisnis, perkebunan, perikanan, petenakan, per-tanian hortikultura (sayur-sayuran, buahbuahan, tanaman hias, dan tanaman obat-obatan), kepriwasatiaan, pemeliharaan lingkungan hidup sehingga terjadi kese-suasian, keselarasan, dan keseimbangan yang dinamis. Kurikulum selain mengacu pada kareteristik peserta didik, perkembangan ilmu dan teknologi pada zamannya yang mengaju kepada kebutuhan-kebutuhan masyarakat.

\section{Kesimpulan}

Upaya pengembangan kurikulum PAI memerlukan landasan yang jelas dan kokoh, sehingga tidak mudah terombang-ambing oleh arus transformasi dan inovasi pendidikan dan pembelajran yang begitu dahsyat sebagaimana yang terjdai akhir-akhir ini. Apabila inovasi itu pada umumnya cenderung bersifat top- 
Daftar Pustaka

Bukhori, Mochtar, Spektrum Problematika Pendidikan di Indonesia. Jakarta: Tirta Wacana Yogya. 2016

Dakir, Perencanaan dan Pengembangan Kurikulum, Jakarta: Rineka Cipta, 2014

Fatah, Nanang, Landasan pengembangan Pendidikan, Bandung: PT Remaja Rosdakarya, 2016

Hamalik, Oemar, Manajemen pengembangan Kurikulum, Bandung: PT Remaja Rosdakarya, 2016

Muhaimin, Pengembangan Kurikulum Pendidikan Agama Islam, Jakarta: PT Raja Grafido Persada, 2017

Nandika, Dodi, Pendidikan di Tengah Gelombang Perubahan, Jakarta: Pustaka LP3ES, 2017

Nasution, Harun, Islam ditinjau dari berbagai Aspeknya, Jakarta: UI Press, 2015

Pendidikan, Departemen, Nasional, Kamus Besar Bahasa Indonesia Jakarta: Balai Pustaka, 2015

Rijono, Nanang, "Kontribusi Kecil untuk Dunia Pendidikan Indonesia", (online) available: http://rijono.wordpress.com/ 2008/02/28/kurikulum2004-kbk-kurikulum-2006ktsp-memang-berbeda- 